\title{
506 曲がり管式血流量計の曲げ角度が流量計測に及ぼす影響
}

Effect of bending angle of a blood flow meter using a curved pipe on flow rate measurement

$\begin{array}{llll} & \text { 斉藤 } & \text { 匠 (東理大院) } \\ \text { 迫田 } & \text { 大輔 (産総研) } \\ \text { 正 川口 } & \text { 靖夫 (東理大) } \\ \text { 正 丸山 } & \text { 修 (産総研) }\end{array}$

\author{
小阪 亮 (産総研) \\ 正 西田 正浩（産総研） \\ 正 山根 隆志（神戸大）
}

Takumi SAITO and Yasuo KAWAGUCHI, Tokyo University of Science, 2641 Yamazaki, Noda, Chiba Ryo KOSAKA, Daisuke SAKOTA, Masahiro NISHIDA and Osamu MARUYAMA

National Institute of Advanced Industrial Science and Technology, 1-2-1 Namiki, Tsukuba, Ibaraki Takashi YAMANE, Kobe University, 1-1 Rokkodai, Nada, Kobe, Hyogo

We have developed a blood flow meter using a curved pipe. In this study, we investigated the influence of the bending angle of a curved pipe on flow measurement by means of computational fluid dynamics (CFD) analysis. We analyzed the pressure distribution and the secondly flow in the curved pipe. As a result, the measurement positions for the blood flow were determined. Corresponding to increase of the bending angle, although the measurement accuracy was improved, the influence of the secondary flow was increased.

Key words : Blood Flow Meter, Computational Fluid Dynamics

\section{1. 緒言}

埋込み型補助人工心臓の駆動状態や，補助人工心臓を適用 された患者の生理学的情報を確認するため, 補助人工心臓の 血流量を計測することは重要である。そこで，補助人工心臟 と生体を繋ぐ曲がり管を流量センサとして利用する曲がり管 式血流量計を開発している ${ }^{1)}$ 。本血流量計は，遠心力が作用 する位置と, 遠心力の影響の少ない位置に歪ゲージを貼り付 け，各ゲージから求められる，曲がり管で生じる差圧から血 流量を計測している。しかし，曲がり管の曲げ角度は補助人 工心臓の種類によって異なるのに対し，これまで，本血流量 計は曲げ角度を 120 度に固定していた. そこで, 本研究では, 曲がり管式血流量計を曲げ角度 120 度以外の曲がり管を有す る人工心臓へ適用するため，曲げ角度が流量計測に及ぼす影 響を, 数值流体力学 (CFD) 解析を用いて評価した。

\section{2. 解析モデル及び解析手法}

曲げ角度の異なる曲がり管として, 曲げ角度 30 度, 60 度, 90 度, 120 度の曲がり部を有する曲がり管を解析対象とした。 図 1 に曲げ角度 30 度の解析モデルを例として示す. 各モデル は流入口から流出口まで, 直径 $12 \mathrm{~mm}$ の円形断面の流路であ り, 流入口から曲がり部開始地点までの距離を $50 \mathrm{~mm}$, 曲が り部終了地点から流出口までの距離を $50 \mathrm{~mm}$ とした。曲がり 部の曲率半径は $30 \mathrm{~mm}$ とした.

モデルの格子生成には, メッシュ生成ソフトである ANSYS Meshing(ANSYS Inc.)を使用した. 各モデルの格子数，節点数 がそれぞれ約 300,000 から約 400,000 になるよう, 非構造格子 を用いてメッシュを生成した. CFD 解析には市販の流体解析 ソフトである ANSYS CFX 12.0.1(ANSYS Inc.)を用い，定常解 析を行った. 解析アルゴリズムは有限体積法である. 境界条 件として, 流入口に一般的な補助人工心臓の平均流量である $5 \mathrm{~L} / \mathrm{min}$ を, 流出口に圧力 $100 \mathrm{mmHg}$ を与えた. 壁の境界条件 は，一様にすべりなしとした。作動流体の物性値は，血液の 物性值を模擬した密度 $1,050 \mathrm{~kg} / \mathrm{m}^{3}$ ，粘度 $3.0 \mathrm{mPa} \cdot \mathrm{s}$ とした。 乱流の取り扱いでは，壁面付近で $k-\omega$ モデル，バルク流では $k-\varepsilon$ モデルを用いる, Shear Stress Transport モデルを採用した.

本解析では，まず，管路内の圧力分布を解析することで, 曲げ角度の異なる曲がり管の遠心力の計測位置と静圧補償を 行うための静圧の計測位置を決定した。次に，曲げ角度が流 量の計測精度に及ぼす影響を検討するため, 遠心力の計測位 置と, 静圧補償の計測位置の差圧を算出した. 最後に, 先行 研究 ${ }^{2)}$ から計測位置の断面二次流れが流量計測に影響を及ぼ すことが示唆されているため, 各曲がり管の計測位置におけ る断面二次流れを解析した。

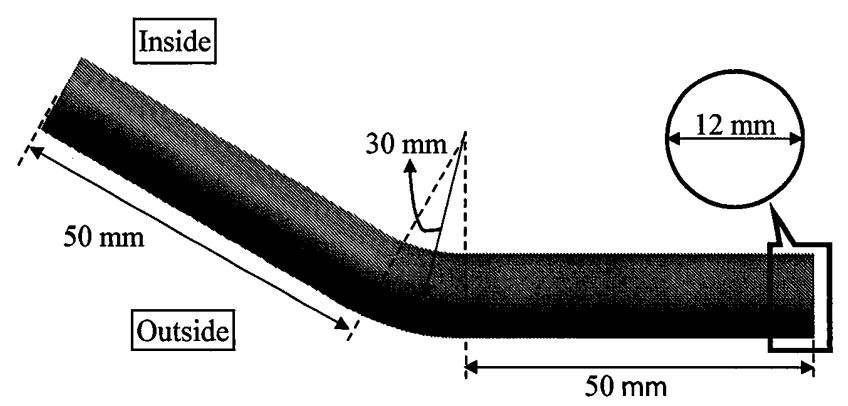

Fig.1 Analyzed curved pipe model

\section{3. 解析結果及び考察}

管路内の圧力分布を解析した結果を表 1 に示す. 遠心力の 計測位置として，管路内の圧力が最大となる位置を求めた. その結果, 曲げ角度 $30,60,90$ および 120 度の曲がり管では, 曲がり部開始地点からそれぞれ 16，32，37 および 38 度の位 置で圧力が最大となった，一方，全ての曲がり管で，曲がり 部終了地点から $10 \mathrm{~mm}$ 離れた地点では遠心力による影響が小 さかった。そのため，この位置を静圧補償の計測位置として 設定した.

次に，曲げ角度が流量の計測精度に及ぼす影響を検討する ため，遠心力の計測位置と静圧補償の計測位置の差圧 $\Delta \mathrm{P}$ を 算出した。 各曲がり管の差圧 $\Delta \mathrm{P}$ と曲がり管の曲げ角度 $\theta$ の 関係を図 2 に示す。

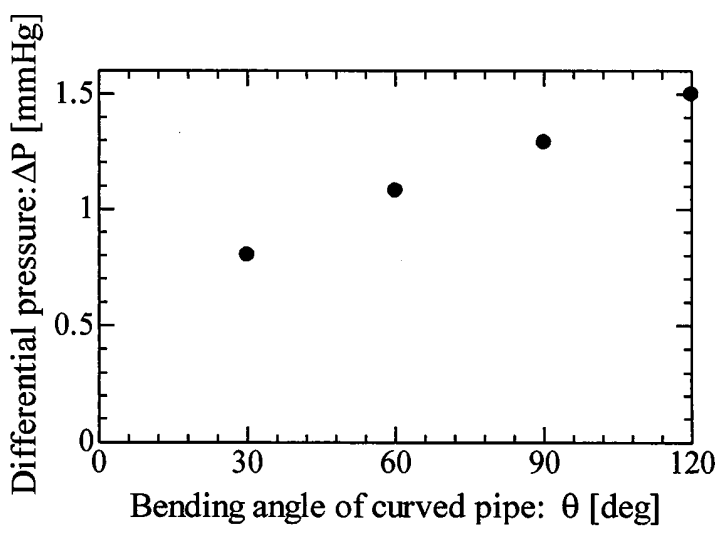

Fig 2. Relationship between differential pressure: $\Delta \mathrm{P}$ and bending angle of curved pipe: $\theta$

茨城講演会講演論文集（共催 日本機械学会関東支部・精密工学会・茨城大学，2014-9-5，日立） 
Table 1 Pressure distribution and maximum pressure position of curved pipe for each model

\begin{tabular}{|c|c|c|c|c|}
\hline $\begin{array}{c}\text { Bending } \\
\text { angle }\end{array}$ & $30^{\circ}$ & $60^{\circ}$ & $90^{\circ}$ & $120^{\circ}$ \\
\hline $\begin{array}{l}\text { Pressure } \\
\text { distribution } \\
\text { and } \\
\text { maximum } \\
\text { pressure } \\
\text { position }\end{array}$ & $\underbrace{100.88}_{\substack{100.06 \\
\text { 99.608 }}}$ & $\underbrace{101.48}_{\substack{99.683 \\
[\mathrm{mmHg}]}}$ & $\underset{[\mathrm{mmHg}]}{109.908}$ & $\underbrace{109.983}_{\substack{100.43 \\
[\mathrm{mmHg}]}}$ \\
\hline
\end{tabular}

Table 2 Velocity distribution of the secondary flow at the measurement point of strain for each model

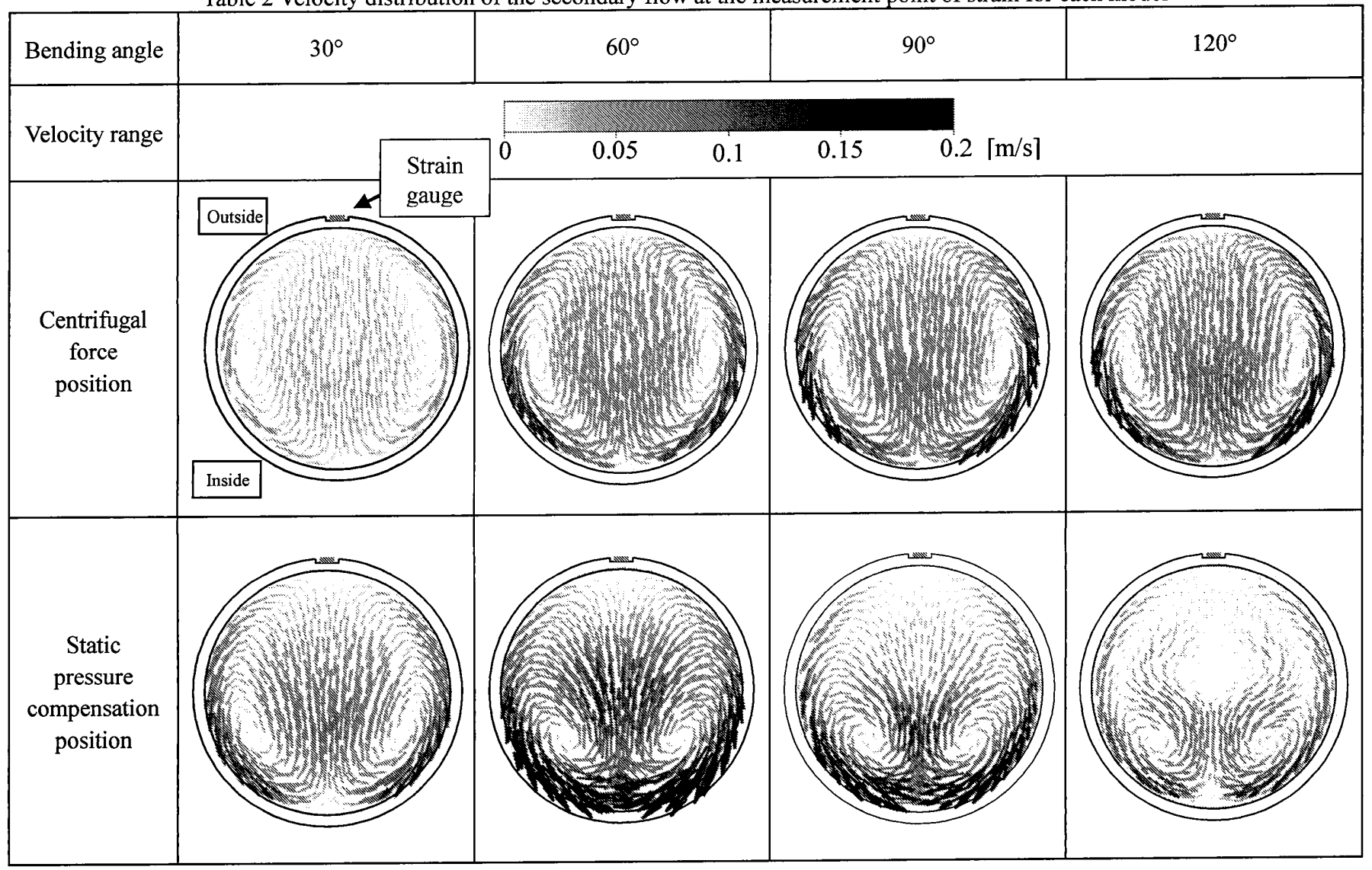

図 2 から曲がり管の曲げ角度を大きくすると，曲がり管に生 じる差圧は増加した。これは曲げ角度が大きくなることによ り，遠心力を受ける区間が長くなり，曲がり部外側の圧力が 増加したためであると考えられる。そのため，曲げ角度の大 きな曲がり管を用いることによって，血流量計の計測精度は 向上すると考えられる.

表 2 に, 各曲がり管の計測位置における断面二次流れの解析 結果を示す，各曲がり管において，遠心力の計測位置では， 流速が異なるもののほぼ同形の二次流れが形成された。流速 の大きさが異なる原因として, 曲げ角度が大きくなるにつれ， 流体が遠心力を受ける区間が長くなるため, 特に管中央の内 側から外側の流れであるセンサ方向の流れの流速が大きくな つていると考えられる。センサ方向の流れは曲代角度が大き くなるとともに，速くなるため，曲げ角度の大きな曲がり管 は曲げ角度の小さな曲がり管と比較して, 歪計測の際に, 二 次流れの影響を受けやすいことが示唆された。一方，静圧補 償の位置では，曲げ角度に関わらず，全ての曲がり管におい て，曲がり部が終了し，遠心力が小さくなったことで，セン サ方向への流れが小さくなっていることが確認できる.つま り, 静圧補償の位置は遠心力の検出位置と比較して, 歪計測 の際に，二次流れの影響は受けにくいことが示唆された。

\section{4. 結言}

本研究では，異なる曲げ角度を有する曲がり管に対して CFD 解析を行い, 曲げ角度が流量計測に及ぼす影響を検討し た. その結果, 管路内の圧力分布より, 遠心力計測位置と静 圧補償位置を決定することができた。 また，曲がり管の曲げ 角度を増加させると, 曲がり管に生じる差圧も増加するため, 計測精度の向上が見込まれるが，一方で，二次流れの影響を 受けやすくなることが示唆された。

\section{5. 参考文献}

(1) R.Kosaka, M.Nishida, O.Maruyama, T.Yamane, "Development of a miniaturized mass-flow meter for an axial flow blood pump based on computational analysis", Journal of Artificial Organs, Vol. 14, No.3(2011), pp.178-84.

（2）福田恭平, 小阪亮, 丸山修, 西田正浩, 川口靖夫, 山根 隆志, “PIV による血液質量流量計の二次流れの計測”, 生 活生命支援医療福祉工学系学会連合大会 2011, OS2-1, 東京, 11, 2011 